Published in final edited form as:

Angew Chem Int Ed Engl. 2008 ; 47(39): 7482-7484. doi:10.1002/anie.200801555.

\title{
Small Molecule Inhibitors of MicroRNA miR-21 Function**
}

\author{
Kiranmai Gumireddy,
}

The Wistar Institute, 3601 Spruce Street Philadelphia, PA 19104, USA

Douglas D. Young,

Department of Chemistry North Carolina State University Raleigh, NC 27695-8204, USA

Xin Xiong,

Department of Chemistry North Carolina State University Raleigh, NC 27695-8204, USA

John B. Hogenesch,

Department of Pharmacology Institute for Translational Medicine and Therapeutics University of

Pennsylvania School of Medicine Philadelphia, PA 19104-6160, USA

Qihong Huang, and

The Wistar Institute, 3601 Spruce Street Philadelphia, PA 19104, USA Fax: (+) 1-215-898-7952

qhuang@wistar.orghttp://www.wistar.org/research_facilities/huang/research.htm

\author{
Alexander Deiters \\ Department of Chemistry North Carolina State University Raleigh, NC 27695-8204, USA Fax: (+) \\ 1-919-515-5079 alex_deiters@ncsu.eduhttp://www4.ncsu.edu/ adeiter/
}

\section{Keywords}

microRNA; inhibitors; cell based assay; medicinal chemistry; cancer

MicroRNAs (miRNAs) have recently emerged as an important class of gene regulators, and their misregulation has been linked to a variety of cancers. Small molecule inhibitors of miRNAs would be important tools to elucidate the detailed mechanisms of miRNA function and provide lead structures for the development of new therapeutics. We are reporting a cellular screen for miRNA pathway inhibitors and the first small molecule modifiers of miRNA function.

miRNAs are single-stranded noncoding RNAs of 21-23 nucleotides. They are a novel class of gene regulators that function by binding to the 3' untranslated region of target messenger RNAs leading to either suppression of their translation or acceleration of their degradation. ${ }^{[1]}$ The majority of miRNAs are initially transcribed as primary miRNAs (primiRNAs), ${ }^{[2]}$ which are further processed in the nucleus by the enzyme Drosha, thus transforming pri-miRNAs into shorter stem-loop-structured, double-stranded RNAs called precursor miRNAs (pre-miRNAs). ${ }^{[3]}$ Pre-miRNAs are then transported from the nucleus to the cytoplasm and are processed by Dicer into mature miRNAs. ${ }^{[4]}$ Mature miRNAs enter the effector complex, called the RNA-induced silencing complex (RISC), to then target singlestranded complementary mRNAs (Supporting Figure 1). ${ }^{[5]}$ It is estimated that miRNAs are

\footnotetext{
** This research has been supported in part by the National Institutes of Health (NS059478-01) and Accelerate Brain Cancer Cure. DDY acknowledges a graduate research fellowship from the ACS Medicinal Chemistry Division. AD is a Beckman Young Investigator and a Cottrell Scholar. QH acknowledges support from the Elsa Pardee Foundation, Breast Cancer Alliance, and the V Foundation.

Correspondence to: Qihong Huang; Alexander Deiters.
} 
involved in the regulation of about $30 \%$ of all genes and almost every genetic pathway. ${ }^{[6]}$ Moreover, recent evidence suggests that they can function as oncogenes and tumor suppressors. ${ }^{[7,8]}$ Thus, small molecule regulation of misregulated miRNAs has the potential to provide a new area of therapeutics. So far, specific miRNA inhibition has been only achieved by antisense nucleic acids. ${ }^{[9]}$ We developed an assay for small molecule inhibitors of miRNA function and discovered potentially specific miRNA pathway inhibitors. Although inhibitors of the siRNA pathway have been identified ${ }^{[10]}$ to our knowledge no small molecule inhibitors of the miRNA pathway have been reported. We selected miR-21 as a target miRNA due to its documented function as an anti-apoptotic factor in cancer cells and its elevated levels in various cancers such as breast, ovarian, and lung cancer as well as glioblastomas. ${ }^{[7,11]}$ Lentiviral reporter constructs for miRNA activity were assembled by introducing the complementary sequences of mature miR-21, the specificity control miR-30, or a negative control linker sequence (a site with no detectable recognition by natural miRNAs) downstream of a luciferase reporter gene (Supporting Figure 2). These plasmids serve as sensors to detect the presence of specific mature miRNAs (Scheme 1).

The reporter constructs were stably introduced into HeLa cells which express high levels of miR-21, but relatively low levels of miR-30. ${ }^{[12]}$ In order to test the miRNA specificity of the reporter system, cells that contained both the Luc-miR-30A reporter construct and a construct expressing exogenous primary miR-30 were assayed. These cells displayed a greatly diminished luciferase signal compared to cells with a mismatched Luc-miR-30A reporter/miR-21 combination (Supporting Figure 3), demonstrating that the Luc-miR-21 and Luc-miR-30A reporters are specific and react only to miR-21 and miR-30, respectively. The ability to detect endogenous miR-21 was proven by the fact that the Luc-miR-21 reporter, when introduced into HeLa cells, led to a $90 \%$ decreased luciferase signal in comparison to the control luciferase-linker construct, visualizing the high level of endogenous miR-21 expression in HeLa cells (Supporting Figure 4). As expected, the miR-30A reporter displayed only a modest decrease since HeLa cells express relatively low levels of endogenous miR-30.

Subsequently, a primary screen of $>1000$ compounds from our own compound collection and the Library of Pharmacologically Active Compounds (Sigma-Aldrich) was conducted at a $10 \mu \mathrm{M}$ compound concentration and an initial hit compound 1 was discovered. This diazobenzene led to an increase of the luciferase signal by $251 \%$ compared to untreated cells (the DMSO control had no effect on the luciferase signal; Supporting Figure 5). Through several rounds of screening and structural modification a preliminary structure-activity relationship was developed (Supporting Figure 6). Acylation and alkylation of the amino group in $\mathbf{1}$ led to diminished activities. However, the screening of a wide range of molecules structurally related to the azobenzene core delivered the highly active compound $\mathbf{2}$ (5-fold increase of the luciferase signal at $10 \mu \mathrm{M}$, Figure 1 and $2 \mathrm{~A}$ ). Other molecules derived from 2 through introduction of an amino or nitro group in the 4' position led to $12 \%$ or $64 \%$ reduced activity, respectively. Other amide substituents displayed a substantial loss of activity (24-53\%), with the exception of allyl and propyl groups, which showed $11 \%$ and $16 \%$ lower activity, respectively. An exchange of the amide for a sulfonamide delivered compounds with no activity and, interestingly, the styrene analog of $\mathbf{2}$ had a $40 \%$ lower activity. Thus far, $\mathbf{2}$ is the most effective small molecule inhibitor of microRNA miR-21 function inducing a $485 \%$ increase in the luciferase reporter signal at $10 \mu \mathrm{M}$. The diazobenzene $\mathbf{2}$ does not display cytotoxic effects at this concentration as determined by an MTT assay (data not shown). Dose response studies from $0-10 \mu \mathrm{M}$ revealed a concentration dependence of the luciferase signal with an $\mathrm{EC}_{50}$ of $2 \mu \mathrm{M}$ (Figure 1).

Several experiments were conducted in order to investigate the mode of action of the inhibitor $\mathbf{2}$. The compound does not affect the luciferase signal in HeLa cells expressing the 
Luc-linker control sequence (Figure 2A), thus indicating that it does not increase the luciferase signal through means other than inhibiting the miRNA pathway. Furthermore, HeLa cells expressing both the miR-30 luciferase reporter construct and miR-30 were treated with 2. In this case, no increase of the luciferase signal was detected (Figure 2A), demonstrating that $\mathbf{2}$ is potentially specific towards miR-21 and does not have a general effect on the common miRNA pathway.

The specificity of $\mathbf{2}$ for the inhibition of miR-21 function was further validated by measuring intracellular miRNA levels via quantitative RT-PCR (Figure 2B). We found that levels of the stably expressed, exogenous mature miR-30, endogenous mature miR-93 and endogenous non-miRNA genes such as E-chaderin, ID1, RAP1A, Fibronectin are not reduced by treatment with 2 (Figure 2B, Supporting Figure 7). Gratifyingly, miR-21 expression is reduced by 78\% compared to the DMSO control in HeLa cells. Quantitative RT-PCR experiments with primers specific for the primary miR-21 (pri-miR-21) sequence but not mature or precursor miR-21 revealed that the pri-miR-21 levels in cells treated with 2 were reduced by $87 \%$ (Figure 2B). Similar observations were also made in three other cell lines, MCF-7, A172, and MDA-MB-231, which endogenously express miR-21 (Supporting Figure $7 \& 8$ ). These results strongly suggest that compound $\mathbf{2}$ is an inhibitor that targets the transcription of the miR-21 gene into pri-miR-21, but not downstream processes of the common miRNA pathway.

In summary, we developed a method to identify inhibitors of the miRNA pathway in live cells, specifically of miR-21 an important anti-apoptotic factor in several cancers. A screening of $>1000$ small organic molecules followed by a structure activity relationship analysis of an initial hit delivered the azobenzene 2 as a specific and efficient inhibitor of miR-21 expression. Research on miRNAs is still in its infancy and the biogenesis of many miRNAs (including miR-21) is not fully understood, thus specific inhibitors of the miRNA pathway (like 2) will be unique tools for the investigation of miRNAs and their involvement in various types of diseases.

\section{experimental section}

\section{Screening protocol}

HeLa cells were cultured in DMEM and 10\% FBS. 2500 HeLa cells containing the LucmiR-21 construct were plated into each well of a 384-well plate and incubated overnight at $37{ }^{\circ} \mathrm{C}$ with $5 \% \mathrm{CO}_{2}$. Plates were centrifuged for $90 \mathrm{~min}$ at $2,500 \times \mathrm{g}$. Medium was changed $24 \mathrm{~h}$ postinfection and compounds were added to a final concentration of $10 \mu \mathrm{M}$. Luciferase signals were determined 48 hours after compound treatment using a Bright-Glo luciferase assay kit (Promega) according to the manufacturer's protocol. The data of three independent experiments was averaged.

\section{Supplementary Material}

Refer to Web version on PubMed Central for supplementary material.

\section{references}

1. a Carthew RW. Curr. Opin. Genet. Dev. 2006; 16:203-208. [PubMed: 16503132] b He L, Hannon GJ. Nat. Rev. Genet. 2004; 5:522-531. [PubMed: 15211354] c Bartel DP. Cell. 2004; 116:281-297. [PubMed: 14744438]

2. Cullen BR. Mol. Cell. 2004; 16:861-865. [PubMed: 15610730]

3. a Denli AM, Tops BB, Plasterk RH, Ketting RF, Hannon GJ. Nature. 2004; 432:231-235. [PubMed: 15531879] b Gregory RI, Yan KP, Amuthan G, Chendrimada T, Doratotaj B, Cooch N, Shiekhattar 
R. Nature. 2004; 432:235-240. [PubMed: 15531877] c Lee Y, Ahn C, Han J, Choi H, Kim J, Yim J, Lee J, Provost P, Radmark O, Kim S, Kim VN. Nature. 2003; 425:415-419. [PubMed: 14508493]

4. a Bernstein E, Caudy AA, Hammond SM, Hannon GJ. Nature. 2001; 409:363-366. [PubMed: 11201747] b Grishok A, Pasquinelli AE, Conte D, Li N, Parrish S, Ha I, Baillie DL, Fire A, Ruvkun G, Mello CC. Cell. 2001; 106:23-34. [PubMed: 11461699] c Hutvagner G, McLachlan J, Pasquinelli AE, Balint E, Tuschl T, Zamore PD. Science. 2001; 293:834-838. [PubMed: 11452083] d Ketting RF, Fischer SE, Bernstein E, Sijen T, Hannon GJ, Plasterk RH. Genes. Dev. 2001; 15:2654-2659. [PubMed: 11641272] e Yi R, Qin Y, Macara IG, Cullen BR. Genes. Dev. 2003; 17:3011-3016. [PubMed: 14681208]

5. a Hammond SM. Curr. Opin. Genet. Dev. 2006; 16:4-9. [PubMed: 16361094] b Hammond SM, Bernstein E, Beach D, Hannon GJ. Nature. 2000; 404:293-296. [PubMed: 10749213] c Hutvagner G, Zamore PD. Science. 2002; 297:2056-2060. [PubMed: 12154197]

6. Hwang HW, Mendell JT. Br. J. Cancer. 2006; 94:776-780. [PubMed: 16495913]

7. Chan JA, Krichevsky AM, Kosik KS. Cancer Res. 2005; 65:6029-6033. [PubMed: 16024602]

8. a Cimmino A, Calin GA, Fabbri M, Iorio MV, Ferracin M, Shimizu M, Wojcik SE, Aqeilan RI, Zupo S, Dono M, Rassenti L, Alder H, Volinia S, Liu CG, Kipps TJ, Negrini M, Croce CM. Proc. Natl. Acad. Sci. U.S.A. 2005; 102:13944-13949. [PubMed: 16166262] b He L, Thomson JM, Hemann MT, Hernando-Monge E, Mu D, Goodson S, Powers S, Cordon-Cardo C, Lowe SW, Hannon GJ, Hammond SM. Nature. 2005; 435:828-833. [PubMed: 15944707] c Zhang L, Huang J, Yang N, Greshock J, Megraw MS, Giannakakis A, Liang S, Naylor TL, Barchetti A, Ward MR, Yao G, Medina A, O'Brien-Jenkins A, Katsaros D, Hatzigeorgiou A, Gimotty PA, Weber BL, Coukos G. Proc. Natl. Acad. Sci. U.S.A. 2006; 103:9136-9141. [PubMed: 16754881]

9. Meister G, Landthaler M, Patkaniowska A, Dorsett Y, Teng G, Tuschl T. Mol. Cell. 2004; 15:185197. [PubMed: 15260970]

10. Chiu YL, Dinesh CU, Chu CY, Ali A, Brown KM, Cao H, Rana TM. Chem. Biol. 2005; 12:643648. [PubMed: 15975509]

11. a Schetter AJ, Leung SY, Sohn JJ, Zanetti KA, Bowman ED, Yanaihara N, Yuen ST, Chan TL, Kwong DL, Au GK, Liu CG, Calin GA, Croce CM, Harris CC. Jama. 2008; 299:425-436. [PubMed: 18230780] b Si ML, Zhu S, Wu H, Lu Z, Wu F, Mo YY. Oncogene. 2007; 26:2799_ 2803. [PubMed: 17072344] c Iorio MV, Ferracin M, Liu CG, Veronese A, Spizzo R, Sabbioni S, Magri E, Pedriali M, Fabbri M, Campiglio M, Menard S, Palazzo JP, Rosenberg A, Musiani P, Volinia S, Nenci I, Calin GA, Querzoli P, Negrini M, Croce CM. Cancer Res. 2005; 65:70657070. [PubMed: 16103053]

12. Schmittgen TD, Jiang J, Liu Q, Yang L. Nucleic Acids Res. 2004; 32:e43. [PubMed: 14985473] 


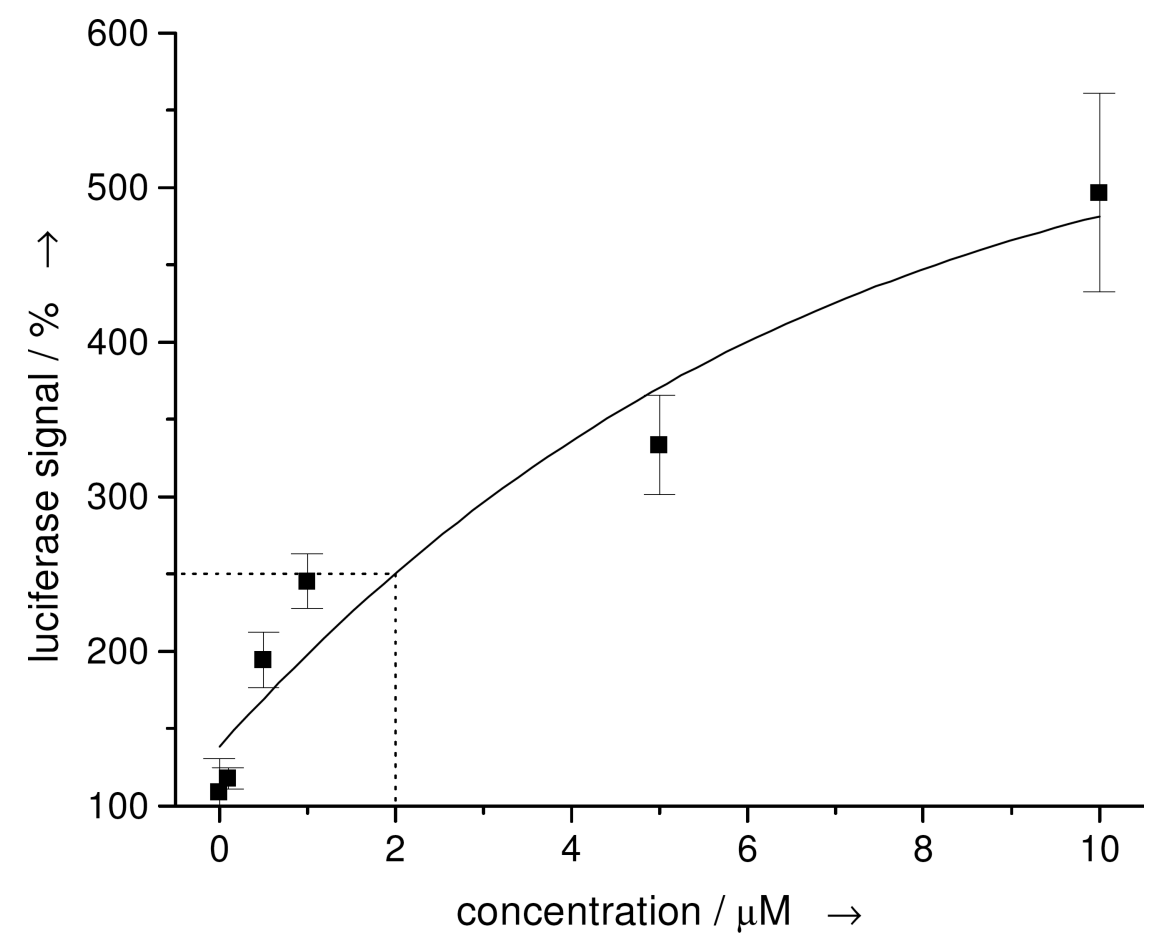

Figure 1.

Dose-response curve of 2 , revealing an $\mathrm{EC}_{50}$ of $2 \mu \mathrm{M}$ and a luciferase signal increase of $\sim 500 \%$ at $10 \mu \mathrm{M}$. The error bars represent the standard deviation from three independent measurements. 

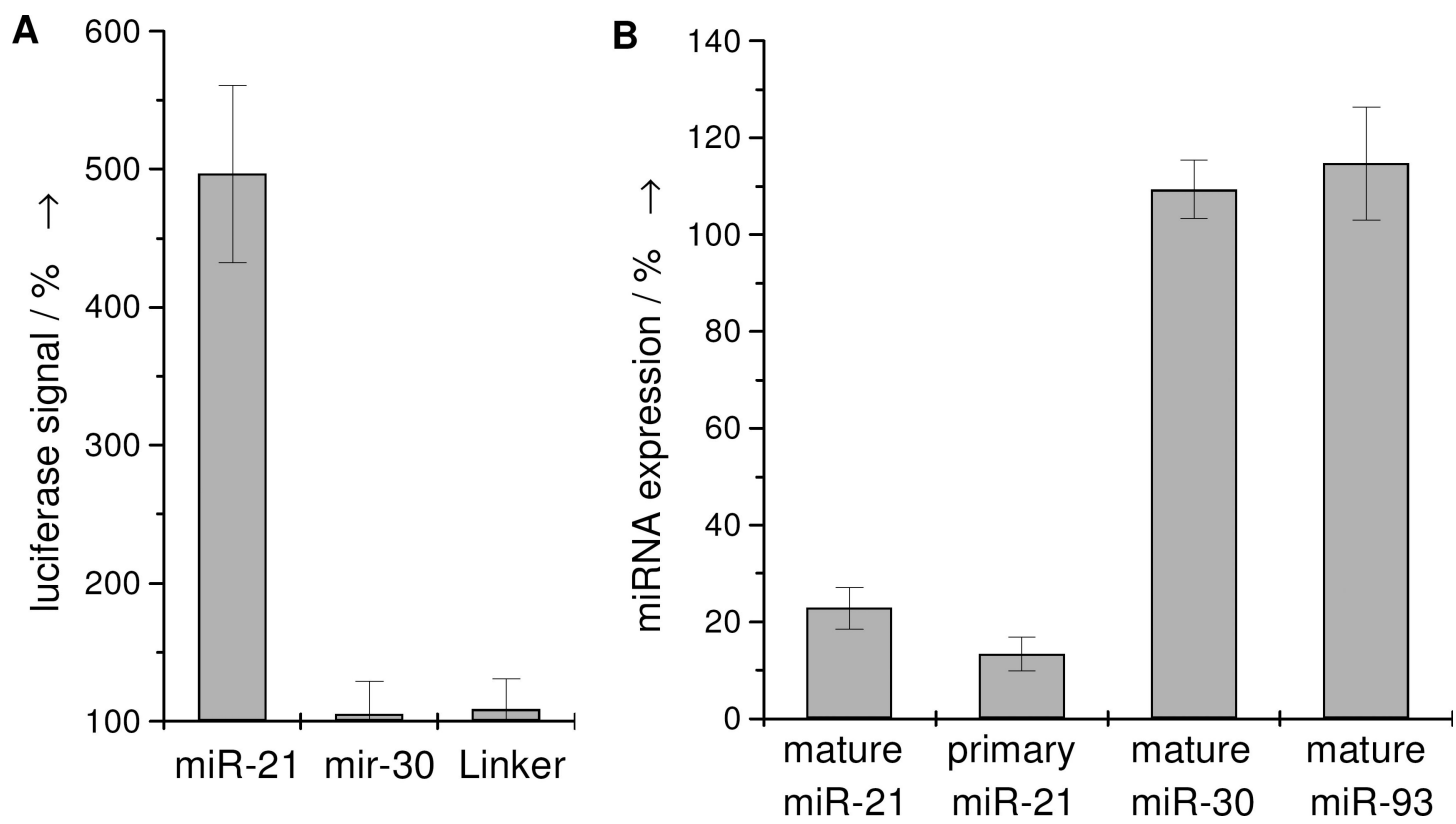

Figure 2.

A) Change in luciferase signal of cells treated with $2(10 \mu \mathrm{M})$ relative to a DMSO control. B) Mature or primary miRNA levels in cells treated with $2(10 \mu \mathrm{M})$ relative to a DMSO control, as determined by quantitative RT-PCR. The error bars represent the standard deviation from three independent measurements. 

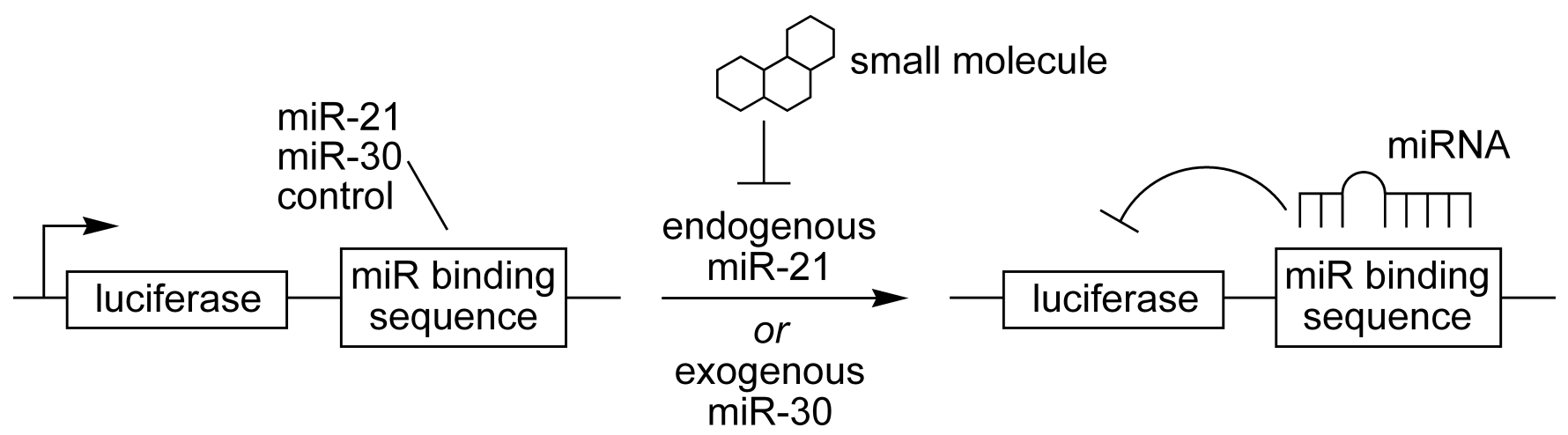

Scheme 1.

Luciferase expression under control of a miRNA binding sequence in the 3' untranslated region (3' UTR) provides an efficient miRNA assay. Endogenous miR-21 (HeLa cells) or exogenous miR-30 downregulate luciferase activity when paired with their specific binding sequence. 